\title{
Does Zoom allow for efficient and meaningful group work? Translating staff development for online delivery during Covid- 19
}

\author{
Hazel Ruth Corradi \\ University of Bath, UK
}

Keywords: Covid-19; group work; assessment; feedback; online workshop; jigsaw.

\section{The challenge}

As an academic staff developer, I am responsible for the delivery of a 2.5-hour stand-alone workshop to support probationary lecturers in developing their assessment and feedback practice. The goal of the workshop is both to introduce key ideas and practices that shape assessment and feedback in UK Higher Education and provide a starting point for participants to develop a reflective case study for their Fellowship of the Higher Education Academy (FHEA) claim (Advance HE, 2019), which is a requirement for their probation. The new challenge facing me during the pandemic of making the workshop suitable for teaching on Zoom made me evaluate which of my teaching values from previous in-person learning I wanted to embed in the design.

I decided I wanted the workshop to be based around group work, as this builds community, and our community is the place where we can build and support the norms of good practice (Smyth, 2013). I feel that supporting academics in building cross-university networks benefits their professional opportunities. Also, conversations with peers are absolutely required for good mental health, especially when working from home (Kember and Murphy, 1994, p.179). To address the additional challenge of a large volume of potential content, I decided to embed choice into the design, allowing participants to choose an article to read and discuss with the idea that they may later be able to use it to support their claim (Kember and Murphy, 1994, p.79). I value choice as it offers a sense of agency in what is a compulsory workshop. Also, it allows probationers to focus their 
development on one aspect of this broad topic so the workshop can be relevant for them at the point they attend (Evans and Boucher, 2015).

As I was designing this in the early autumn of 2020, I was reflecting on both my experience of teaching online workshops and being a participant. I had observed that once in a Zoom break-out room, no one has access to the information from the main room, but also that teachers can only send a short line of text to the rooms. Consequently, I decided the best approach would be to share the information separately on a different platform. Additionally, clarifying tasks seems to be more difficult online as everyone is sent to a room regardless of whether the facilitator has noticed whether the participants know what they should be doing (my experience as a learner!). I wanted to avoid this pitfall by making the plan for the session and the activities available beforehand on a separate platform.

\section{The response}

\section{The design and rationale}

As my expected group size was 20-30, I picked five topics/articles for the participants to choose from, anticipating four or five groups of four-six people (see Figure 1 for topics and Figure 2 for workshop schedule). To ensure participants understood the plan, they always had access to the instructions for the activities and the materials; these were created as webpages within MSTeams as our institution uses Office 365. Detailed instructions of how to access these resources on MSTeams were provided with the invite email and participants were encouraged to ensure they could navigate the pages before attending.

On the MSTeams page, participants could sign up to a slot for the topic they wished to discuss. The slot also allocated them a portion of the article to read and in some cases, a team role such as discussion facilitator or group presenter to enable the group to function smoothly with less awkwardness, as recommended by Strawson (2012, p.71). I modified the number of sign-up slots for each delivery to match the number of participants to ensure the four key topics were covered. Participants were given time during the session to read their portion of the article guided by comprehension and reflective questions to help them synthesise their reading quickly and to act as a focal point (Strawson, 2012, p.105). The questions on the MSTeams shared workspace allowed the groups to pool their ideas. The groups then had 30 minutes to discuss their thoughts from reading the article in their Zoom 
break-out rooms to bring the topic together, following the jigsaw method (Strawson, 2012, p.33). As part of this, each group was asked to decide on some key points, or questions, to share with the class. As the facilitator, I visited the group discussions to listen, prompt additional ideas, answer questions, and get to know the participants. Trammell and LaForge (2017) highlight how being socially present at an online class is important for ensuring students feel engaged in the learning. When we reconvened as a whole class the group presenters informally fed-back the learning from the groups (Strawson, 2012, p.50). Each group was given about five minutes. I responded briefly to each of these participant reports, highlighted further questions to consider, and pointed out any extra things that others might find useful from the article. In this way, participants were able to share ideas that might be relevant to them in future and discover which of the other articles may be useful for their FHEA claim.

\section{Recommendations}

My observations from running three of these workshops this year convinced me that the combination of break out rooms on Zoom combined with a shared workspace on MSTeams supported good staff engagement, productive group discussions, and community building. Additionally, the element of choice worked synergistically to encourage engagement and ownership of the learning opportunity. My observations have been supported by positive responses to the end of session Zoom evaluation quizzes and unsolicited comments on the usefulness of the session. My recommendations stem from my reflections on these observations.

1. Providing all the materials and instruction in one place facilitates online group work running smoothly and to time.

2. Sharing out tasks within and between the groups allows rich and informed discussions within the break-out rooms and helpful summaries to be returned to the rest of the class.

3. Encouraging a small amount of organisation before the session to allow it to run smoothly may be preferred by participants to being required to do preparatory work, such as reading the article beforehand. The organisation allows better use of the workshop time as tasks are engaged with more promptly and in-depth (Trammell and LaForge, 2017). 
4. The additional option to digest the plan and start the tasks beforehand if desired makes the session more inclusive as it allows for clarification in advance.

From my experience, it is a strength to reflect on our values surrounding classroom practice as well as the practicalities of the learning environment when planning teaching. This has allowed me to model several aspects of effective online teaching as well as allowing the participants to engage deeply with the topic.

Figure 1. Articles for group discussion.

\begin{tabular}{|c|c|}
\hline Topic & Article \\
\hline Authentic assessment & $\begin{array}{l}\text { Villarroel, V., Boud, D., Bloxham, S., Bruna, D. and Bruna, } \\
\text { C. (2020) 'Using principles of authentic assessment to } \\
\text { redesign written examinations and } \\
\text { tests', Innovations in Education and Teaching } \\
\text { International, 57(1), pp.38-49. } \\
\text { https://doi.org/10.1080/14703297.2018.1564882. }\end{array}$ \\
\hline Fair assessment & $\begin{array}{l}\text { Bloxham, S. Hughes, C. and Adie, L. (2016) 'What's the } \\
\text { point of moderation? A discussion of the purposes } \\
\text { achieved through contemporary moderation practices', } \\
\text { Assessment \& Evaluation in Higher Education, 41(4), } \\
\text { pp.638-653. } \\
\text { https://doi.org/10.1080/02602938.2015.1039932 }\end{array}$ \\
\hline Feedback for learning & $\begin{array}{l}\text { Carless, D. and Winstone, N. (2020) 'Teacher feedback } \\
\text { literacy and its interplay with student feedback literacy', } \\
\text { Teaching in Higher Education. } \\
\text { https://doi.org/10.1080/13562517.2020.1782372. }\end{array}$ \\
\hline $\begin{array}{l}\text { Helping students } \\
\text { learn from feedback }\end{array}$ & $\begin{array}{l}\text { Advance HE (2016) The Developing Engagement with } \\
\text { Feedback Toolkit (DEFT) Available at: https://www.advance- } \\
\text { he.ac.uk/knowledge-hub/developing-engagement- } \\
\text { feedback-toolkit-deft (Accessed: } 19 \text { August 2021). }\end{array}$ \\
\hline
\end{tabular}


Figure 2. Timetable of activities for Assessment and Feedback Workshop sent to participants beforehand.

\begin{tabular}{|l|l|}
\hline Time & Activity \\
\hline 9.30 & Introduction \\
\hline 9.45 & Sign up for group -read paper/resource \\
\hline 10.15 & $\begin{array}{l}\text { Meet with group to discuss questions } \\
\text { Make notes } \\
\text { Assign a speaker to feedback to group }\end{array}$ \\
\hline 10.45 & Screen break \\
\hline 11.00 & $\begin{array}{l}4 \times \text { min presentations (4-5 mins report back 3-4 mins questions) -people } \\
\text { write questions in chat }\end{array}$ \\
\hline 11.40 & Any other questions, tips on writing for A3 UKPSF \\
\hline 12.00 & Finish -option to stay behind to ask about A3 UKPSF \\
\hline
\end{tabular}

\section{References}

Advance-HE (2019) UK Professional Standards Framework (UKPSF). Available at: https://www.advance-he.ac.uk/guidance/teaching-and-learning/ukpsf (Accessed: 30 June 2021).

Evans, M. and Boucher, A. R. (2015) 'Optimizing the power of choice: supporting student autonomy to foster motivation and engagement in learning', Mind, Brain, and Education, 9, pp.87-91. https://doi.org/10.1111/mbe.12073.

Kane, R., Sandretto, S. and Heath, C. (2004) 'An investigation into excellent tertiary teaching: Emphasising reflective practice', Higher Education, 47, pp.283-310.

Kember, D. and Murphy, D. (1994) 53 Interesting Activities for Open Learning Courses Bristol: Technical and Educational Services Ltd.

Smyth, R. (2003) 'Concepts of change: enhancing the practice of academic staff development in higher education', International Journal for Academic Development, 8(1-2), pp.51-60. https://doi.org/10.1080/1360144042000277937. 
Strawson, H. (2012) 53 Interesting Things to Do in Your Seminars and Tutorials. $5^{\text {th }}$ edn. Wicken: The Professional and Higher Partnership.

Trammell, B. A. and LaForge, C. (2017) 'Common challenges for instructors in large online courses: strategies to mitigate student and instructor frustration', Journal of Educators Online, 14(1), pp.1-10.

\section{Author details}

Hazel Corradi is an Academic Staff Developer at the University of Bath. She is a Senior Fellow of the HEA and supports staff in developing fellowship claims. Her background lecturing in Biochemistry sparked many interests including finding innovative ways to assess and give feedback, the use of online technology in teaching, and overcoming maths anxiety in non-mathematicians. 